\title{
Multilevel Antecedents of Organizational Speed: The Exemplary Case of a Small Italian R\&D Organization
}

\author{
Lara Agostini * and Anna Nosella
}

Department of Management and Engineering, University of Padova, 35131 Padova, Italy; anna.nosella@unipd.it
* Correspondence: lara.agostini@unipd.it

\begin{abstract}
The COVID-19 outbreak has compelled many organizations to adapt to a rapidly changing environment. In this context, the aim of this article is to unveil how a small R\&D organization has been able to rapidly take advantage of the opportunities offered by the COVID-19 outbreak and to understand the factors that have enabled organizational speed. Results of the qualitative analysis of this exemplary single case show that a combination of factors at the individual level (i.e., characteristics of the $\mathrm{CEO}$ and collaborators), organizational level (i.e., structure, resources, operative systems and processes, culture), and partner level (i.e., characteristics of the partner portfolio) is required to go through a very fast recognition-decision-execution process.
\end{abstract}

Keywords: organizational speed; dynamic capability; ambidexterity; COVID-19; R\&D organization

Citation: Agostini, L.; Nosella, A. Multilevel Antecedents of Organizational Speed: The Exemplary Case of a Small Italian R\&D Organization. Sustainability 2021, 13, 7502. https://doi.org/ $10.3390 /$ su13137502

Academic Editors: Miltiadis D. Lytras, Abdulrahman Housawi and Basim Alsaywid

Received: 25 May 2021

Accepted: 2 July 2021

Published: 5 July 2021

Publisher's Note: MDPI stays neutral with regard to jurisdictional claims in published maps and institutional affiliations.

Copyright: (c) 2021 by the authors. Licensee MDPI, Basel, Switzerland. This article is an open access article distributed under the terms and conditions of the Creative Commons Attribution (CC BY) license (https:/ / creativecommons.org/licenses/by/ $4.0 /)$.

\section{Introduction}

The COVID-19 outbreak, which the World Health Organization declared a pandemic on 11 March 2020, has disrupted all business environments. Compared with other contagious diseases, COVID-19 appears to be both more deadly and more contagious, thus leading scientists to consider it "the worst health crisis of our times" [1]. Consequently, all COVID-19 health policies have been directed towards decreasing the replication of the disease and saving lives. This situation is posing serious problems for all individuals, organizations, and countries; looking at organizations, the economic shutdown has put pressure on manufacturing, decreased demand, and contracted industrial profits [2], shocking organizations and putting economic sustainability at risk, which has called for attention on this issue [3,4]. However, at the same time, it might also offer a potential opportunity for some organizations, especially for R\&D labs operating in the healthcare industry domain, which has a direct impact on human health and wellbeing.

The topic of how organizations adapt to changes in their external environment is an issue around which there is recent and still open debate. Although the literature has dedicated increasing attention to this matter in recent decades, organizations continue to fail in doing it effectively, especially in the case of discontinuous change [5]. The changes that COVID-19 has brought about are not only discontinuous, but also unexpected, which further contributes to making this challenge tougher. Indeed, an organization needs to be flexible enough to move and reconfigure its organizational resources and processes to cope with environmental changes [6], which is far from being an easy undertaking, especially in certain situations where the key is responding quickly to environmental challenges [7]. In this regard, very recently, Dykes et al. [8] conceptualized organizational speed as "the dynamic Gestalt-like capacity of an organization to quickly identify, assemble, reconfigure, modify, and deploy its organizational processes and activities" [8] (p. 270), which seems to be exactly what firms need in such unexpected situations as the COVID-19 outbreak. They explain that this dynamic capability encompasses three dimensions, namely recognition speed, decision speed, and execution speed, emphasizing the holistic perspective they use to study organizational change, and explicitly calling for further investigation on this underexplored concept, with a particular focus, among others, on antecedents [8]. 
In addition, to the best of our knowledge, strategic issues, related to the broader theme of dynamic capabilities that organizational speed is part of, have mainly been investigated in manufacturing contexts, with some exceptions focusing on service industries (e.g., [9]), thus leaving the domain of R\&D organizations unexplored.

On such bases, this article aims to answer the following research questions: How can an R\&D organization rapidly take advantage of the opportunities offered by the COVID-19 outbreak? What are the factors that enable the organizational speed of an R\&D organization in the face of the COVID-19 outbreak?

For this purpose, we examine a single yet exemplary case of a small Italian R\&D organization that has faced these challenges rapidly by launching several new explorative and exploitative projects to respond to the open questions posed by the COVID-19 outbreak.

This research is particularly relevant because it allows lessons to be learned after a crisis-like situation, so as to take advantage of the positive experience of an organization that was able to turn this difficult situation into an opportunity [4]. This study contributes, from a theoretical and practical standpoint, to the debate surrounding how small R\&D organizations can promptly react to the disruption this new pandemic has brought about and turn challenges into opportunities. From a theoretical perspective, we elaborate on the concept of organizational speed, offering an overarching view on the recognition-decisionexecution process in times of rapid change and associated antecedents at the individual, organizational, and partner levels. In addition, we contribute to the recent stream exploring the connection between the triple bottom-line dimensions of environmental, social, and economic sustainability and the COVID-19 pandemic, with a particular focus on economic sustainability. From a practical perspective, we make managers of small R\&D organizations aware of how they could be prepared to face such disruptive situations, where the only chance to survive is by transforming challenges into opportunities.

The remainder of this article is structured as follows: in the next section, we briefly lay out the theoretical bases for our study, and then we illustrate the methodology that we followed and present the results of our analysis, before discussing them in light of existing studies and highlighting implications for theory and practice.

\section{The COVID-19 Outbreak}

After the first cases of pneumonia in China (Wuhan City, Hubei Province) at the end of 2019, the rapid escalation of coronavirus disease 2019 (COVID-19) led the World Health Organization declare it a global pandemic on 11 March 2020.

It is widely recognized that the COVID-19 pandemic crisis embraces the health, economic, and social domains. In this context, economists, scientists in the pharmaceutical, epidemiology and biology fields, and policy-makers have led the scene of ongoing debates, but the deep impact on work and organizations calls for a managerial and organizational perspective to complete the picture [10].

While being acquainted with all of the serious difficulties that people and organizations are facing, we must also acknowledge the opportunities that such a changing context offers to organizations [11]. Unquestionably, the COVID-19 pandemic has left no alternatives to organizations but to reconsider how to adapt to the new situation in the most suitable way [12]. Therefore, the capacity to rapidly respond to changes has been considered the key to survival, which is assured not only by financial assets in this scenario [13], further confirming the relevance of successfully adjusting to a mutable environment in all of its facets [14].

However, the ability to change is not enough, but rather speed is central; indeed, in a pandemic, "time is so valuable and essential, that the question of costs is far less important than the ability to get to a solution sooner" [15] (p. 410). Based on the rationale that organizations that have transformed to survive through previous crises have been able to change what they do quickly [16], authors of recent publications in the COVID-19 domain stress the prominent role of speed, both in engaging with new ideas and taking actions (e.g., $[11,15,17])$. Organizational capabilities related to such abilities are not simply 
associated with the redeployment of resources, but rather they require other mechanisms, which contributes to increasing the complexity and demands further research [18].

Despite this evidence, "we know little about the novel organizational and change aspects that the disease represents beyond our established and comfortable researching boundaries" [10] (p. 263).

On such premises, we aim to take advantage of the unique chance to carry out phenomenon-driven research, i.e., shaping research as the phenomenon occurs $[10,19]$, which provides the perfect conditions for conducting research on organizational speed in the COVID-19 pandemic scenario.

\section{Theoretical Background}

One of the key issues in the strategic management field relates to modifications in the environment and the subsequent organizational adaptation on the part of firms through their strategic changes [20]. The literature has widely recognized the importance of strategic change, especially in dynamic environments, and has associated it with the reconfiguration of the resources and capabilities an organization possesses (e.g., [21]). In this context, agility and flexibility are the most used terms by the literature to refer to the ability organizations have to adapt to the changing environment and satisfy market demand [22]. However, the two terms (i.e., flexibility and agility) are often used interchangeably, blurring the boundaries between them [22]. Recently, some articles have tried to shed light on this issue, highlighting that, since "agility emphasizes speed and flexibility as the primary attributes of an agile organization" [23], flexibility seems to be just a component of agility, which is a more encompassing concept. In other words, agility has been recognized by some authors as a natural evolution of flexibility since fast market changes and global competition, which characterize the current competitive arena, have also emphasized the need for speed: flexibility is thus "an agility capability, among other capabilities such as responsiveness or speed" [22] (p. 1138). Along the same lines, Singh et al. [24] and, more recently, Baškarada and Koronios [25] further argue that agility enables a company to respond to the external stimuli producing changes along two independent dimensions: magnitude of change and rate of variety change, which respectively refer to flexibility and speed relative to the competitors. Besides flexibility and speed, Walter [26], in her up-to-date literature review, also identifies responsiveness and competency as the main agility capabilities, all falling under the broader umbrella of dynamic capabilities [26]. Our article is theoretically grounded in this literature and focuses on one of the dimensions of agility, namely organizational speed, which, in the face of the COVID-19 scenario, seems to be a winner and a needed capability for companies not deeply investigated by the literature so far [25]. Indeed, organizational speed can be considered one of the components of agility, even though it emphasizes rapidity, based on the idea that "for action to occur-and occur quickly when conditions warrant-the firm must be alert to the need for action, quickly decide what to do, and have the capability to execute the action" [8] (p. 272). Organizational speed is thus composed of three main dimensions: recognition speed, which is the speed with which an organization recognizes opportunities and challenges; decision speed, which is the speed with it reaches decisions to act; and execution speed, which is the speed with which it mobilizes resources, processes, and activities for the implementation of an initiative [8]. While so far studies on organizational speed are scant, studies on agility have mainly embraced the manufacturing industry, leaving R\&D organizations and laboratories under-investigated; only recently some articles, focused on the broader concept of dynamic capabilities, have started investigating R\&D and technology-based organizations. To provide an overview of the studies on this issue in the R\&D context, we performed a search in ISI Web of Science (WoS) combining the keywords "R\&D lab*" OR "innov* lab" OR "research lab*" OR "research cent" OR "R\&D organi*" OR "technologybased" with the keyword "dynamic capabilit"", both in the Topic (title, abstract, keywords). Results yielded 90 articles, which, after filtering by WoS categories (Management, Business), document type (Article, Review), and language (English), decreased to 58. After reading 
the full text, we identified 17 articles that fit well with the domain of interest. Table 1 exhibits some details of these articles, showing some first evidence concerning the paucity of literature in this area.

Articles can be divided into two main groups where the former contains the articles that assess the impact of dynamic capabilities on firm performance, whereas the latter contains those that investigate the antecedents. Overall, articles in the first group prove that different dynamic capabilities, such as R\&D and marketing capabilities [27], absorptive, innovative, and adaptive capabilities (e.g., [28]), and organizational capability [29,30], play a positive role in enhancing different dimensions of firm performance. 
Table 1. Overview of the literature on dynamic capabilities in R\&D and technology-based organizations.

\begin{tabular}{|c|c|c|c|c|c|}
\hline Reference & Purpose & DC Investigated & Main Evidence & Setting & Methodology \\
\hline $\begin{array}{c}\text { do Nascimento Welter et al. } \\
\text { [31] }\end{array}$ & $\begin{array}{l}\text { To identify the instruments } \\
\text { and organizational } \\
\text { mechanisms that provide the } \\
\text { development of the } \\
\text { innovative capacities of } \\
\text { companies }\end{array}$ & Innovative capacity & $\begin{array}{l}\text { The process of developing the } \\
\text { innovative capacity of companies } \\
\text { was studied, and this development } \\
\text { occurred through behaviors and } \\
\text { skills, routines, and processes and } \\
\text { mechanisms of learning and } \\
\text { knowledge governance that } \\
\text { underpin the development of the } \\
\text { product, process, and behavioral } \\
\text { dimensions. }\end{array}$ & $\begin{array}{l}\text { Small technology-based } \\
\text { institutions in Brazil }\end{array}$ & $\begin{array}{l}\text { Qualitative-multiple } \\
\text { case study }\end{array}$ \\
\hline Deligianni et al. [32] & $\begin{array}{l}\text { To examine the nature of the } \\
\text { relationship between } \\
\text { technological competence } \\
\text { and product innovation, and } \\
\text { the moderating effects of the } \\
\text { entrepreneur's political } \\
\text { competence and prior } \\
\text { start-up experience }\end{array}$ & $\begin{array}{l}\text { Entrepreneurial political } \\
\text { capability }\end{array}$ & $\begin{array}{l}\text { Technological competence and } \\
\text { entrepreneurial competences are } \\
\text { key contingencies that influence } \\
\text { resource orchestration efficiency in } \\
\text { the context of new venture } \\
\text { innovation. }\end{array}$ & $\begin{array}{l}\text { New technology-based } \\
\text { ventures in Greece }\end{array}$ & Quantitative \\
\hline Salehi et al. [33] & $\begin{array}{l}\text { To understand how the roles } \\
\text { played by network actors } \\
\text { evolve during the } \\
\text { development and } \\
\text { commercialization process of } \\
\text { an emerging technology and } \\
\text { what operational and } \\
\text { dynamic capabilities are } \\
\text { developed by actors through } \\
\text { collaboration }\end{array}$ & DC in general & $\begin{array}{l}\text { Actors developed sensing } \\
\text { capabilities in the pre-collaboration } \\
\text { stage, which drove joint new } \\
\text { product development. During the } \\
\text { collaboration, seizing capabilities } \\
\text { were developed where resource } \\
\text { commitment and alignment of } \\
\text { resources among actors were } \\
\text { essential. Capabilities gained } \\
\text { through commercialization and } \\
\text { large-scale production were } \\
\text { predominantly transforming } \\
\text { capabilities where actors realigned } \\
\text { their structure and had a positive } \\
\text { impact on capability development } \\
\text { in the wider network. }\end{array}$ & $\begin{array}{l}\text { Technology-based start-ups } \\
\text { in a network context }\end{array}$ & $\begin{array}{c}\text { Qualitative- - single case } \\
\text { study }\end{array}$ \\
\hline
\end{tabular}


Table 1. Cont.

\begin{tabular}{|c|c|c|c|c|c|}
\hline Reference & Purpose & DC Investigated & Main Evidence & Setting & Methodology \\
\hline Deakins and Bensemann [34] & $\begin{array}{c}\text { To investigate the nexus } \\
\text { between entrepreneurial } \\
\text { learning and the innovation } \\
\text { process }\end{array}$ & Entrepreneurial learning & $\begin{array}{l}\text { Entrepreneurial learning has a } \\
\text { critical role in the innovation } \\
\text { process, enabling TBSFs to } \\
\text { overcome resource constraints and } \\
\text { challenges in a lean contextual } \\
\text { environment such as New Zealand. }\end{array}$ & $\begin{array}{l}\text { Technology-based new firms } \\
\text { (TBNFs) in the agri-business } \\
\text { sector in New Zealand }\end{array}$ & Qualitative interviews \\
\hline Jensen and Clausen [35] & $\begin{array}{l}\text { To examine the origins of } \\
\text { exploration and exploitation } \\
\text { capabilities in NTBFs }\end{array}$ & $\begin{array}{l}\text { Exploration and exploitation } \\
\text { capabilities }\end{array}$ & $\begin{array}{l}\text { There is an effect of exploitation } \\
\text { and exploration behavior on } \\
\text { capability emergence, and this } \\
\text { effect is mediated through routines } \\
\text { for deliberate learning. }\end{array}$ & $\begin{array}{l}\text { New technology-based firms } \\
\text { (NTBFs) in Norway }\end{array}$ & Quantitative \\
\hline Cho et al. [36] & $\begin{array}{l}\text { To propose an assessment } \\
\text { framework for research and } \\
\text { development }(\mathrm{R} \& D) \\
\text { innovation capabilities }\end{array}$ & $\begin{array}{l}\text { R\&D-based innovation } \\
\text { capabilities }\end{array}$ & $\begin{array}{l}\text { Conceptualization of R\&D-based } \\
\text { innovation capabilities as } \\
\text { composed of management, } \\
\text { innovation, planning, and } \\
\text { implementation capabilities; a } \\
\text { framework with indices for each } \\
\text { component is presented and tested. }\end{array}$ & $\begin{array}{l}\text { SMEs in technology-based } \\
\text { industries (chemistry, } \\
\text { electronics, } \\
\text { telecommunications, and } \\
\text { semiconductors) }\end{array}$ & $\begin{array}{l}\text { Conceptual + } \\
\text { Qualitative }\end{array}$ \\
\hline Löfsten [30] & $\begin{array}{l}\text { To analyze the organizational } \\
\text { capabilities among NTBFs } \\
\text { and examine how these are } \\
\text { linked to the firms' long-term } \\
\text { survival }\end{array}$ & Organizational capabilities & $\begin{array}{l}\text { Business experience (work } \\
\text { experience, education, } \\
\text { multidisciplinary) of the CEO } \\
\text { positively influences firm survival, } \\
\text { whereas financing and having } \\
\text { international customers do not. }\end{array}$ & NTBFs in Sweden & Quantitative \\
\hline Hutterer et al. [37] & $\begin{array}{l}\text { To investigate how a research } \\
\text { center is able to fulfil } \\
\text { contradictory demands by } \\
\text { scientific and industrial } \\
\text { stakeholders }\end{array}$ & Ambidexterity & $\begin{array}{l}\text { The fundamental abilities for } \\
\text { managing contradictory demands } \\
\text { are located on an individual level, } \\
\text { and it is argued that especially } \\
\text { autonomous, well-educated people } \\
\text { and their competences of } \\
\text { self-organization enable the } \\
\text { research center to be ambidextrous. }\end{array}$ & $\begin{array}{l}\text { Large research center in the } \\
\text { mechatronic sector }\end{array}$ & $\begin{array}{l}\text { Qualitative-single case } \\
\text { study }\end{array}$ \\
\hline
\end{tabular}


Table 1. Cont.

\begin{tabular}{|c|c|c|c|c|c|}
\hline Reference & Purpose & DC Investigated & Main Evidence & Setting & Methodology \\
\hline $\begin{array}{c}\text { Ortín-Ángel and } \\
\text { Vendrell-Herrero [38] }\end{array}$ & $\begin{array}{l}\text { To compare the evolution of } \\
\text { firms' total factor } \\
\text { productivity between } \\
\text { university spin-offs and } \\
\text { NTBFs from a capability } \\
\text { perspective }\end{array}$ & DC in general & $\begin{array}{l}\text { University spin-offs have lower } \\
\text { initial substantive capabilities but } \\
\text { greater dynamic capabilities than } \\
\text { independent NTBFs. }\end{array}$ & $\begin{array}{l}\text { University spin-off and } \\
\text { NTBFs in Spain }\end{array}$ & Quantitative \\
\hline Biedenbach and Müller [28] & $\begin{array}{l}\text { To explore how absorptive, } \\
\text { innovative, and adaptive } \\
\text { capabilities within early } \\
\text { project phases affect project } \\
\text { and portfolio performances in } \\
\text { pharmaceutical and } \\
\text { biotechnology R\&D } \\
\text { organizations }\end{array}$ & $\begin{array}{l}\text { Absorptive, innovative, and } \\
\text { adaptive capabilities }\end{array}$ & $\begin{array}{l}\text { The results show effects of } \\
\text { absorptive, innovative, and } \\
\text { adaptive capabilities on short- and } \\
\text { long-term project performance and } \\
\text { portfolio performance. Absorptive } \\
\text { and adaptive capabilities are the } \\
\text { primary contributors to the } \\
\text { performance outcome, whereas } \\
\text { innovative capabilities are a minor } \\
\text { contributor. }\end{array}$ & $\begin{array}{l}\text { Pharmaceutical and } \\
\text { biotechnology R\&D } \\
\text { organizations }\end{array}$ & $\begin{array}{l}\text { Qualitative- } \\
\text { quantitative } \\
\text { interviews }\end{array}$ \\
\hline Brinckmann and Hoegl [39] & $\begin{array}{l}\text { To examine how teamwork } \\
\text { capability and relational } \\
\text { capability of the } \\
\text { entrepreneurial team affects } \\
\text { the development of new } \\
\text { firms }\end{array}$ & $\begin{array}{l}\text { Relational capability and } \\
\text { teamworking capability }\end{array}$ & $\begin{array}{l}\text { The study finds that the founding } \\
\text { team's initial relational capability is } \\
\text { important for the development of } \\
\text { NTBFs, whereas the founding } \\
\text { team's initial teamwork } \\
\text { capabilities is not. }\end{array}$ & NTBFs in Germany & Quantitative \\
\hline Strehle et al. [40] & $\begin{array}{l}\text { To investigate the impact of } \\
\text { organizational learning as an } \\
\text { endogenous growth driver } \\
\text { for technology-based new } \\
\text { ventures }\end{array}$ & $\begin{array}{l}\text { Strategic planning, financial } \\
\text { planning, and evaluation, } \\
\text { human resource planning, } \\
\text { and evaluation, product } \\
\text { development, marketing and } \\
\text { sales }\end{array}$ & $\begin{array}{l}\text { Eight bundles of management } \\
\text { control systems, which are used as } \\
\text { proxies for the emergence of the } \\
\text { dynamic capabilities strategic } \\
\text { planning, financial planning, and } \\
\text { evaluation, human resource } \\
\text { planning, and evaluation, product } \\
\text { development, marketing and sales, } \\
\text { and partnering, are positively } \\
\text { associated with the growth of the } \\
\text { venture. }\end{array}$ & $\begin{array}{l}\text { Technology-based new } \\
\text { ventures }\end{array}$ & Qualitative \\
\hline
\end{tabular}


Table 1. Cont.

\section{Reference}

\section{Purpose}

To examine perceptions regarding the practice of innovation in the US Air Force's science and technology (S\&T) community
Innovation management as a form of organizational capability
Thal and Shahady [29]
DC Investigated

Main Evidence

The primary reasons the $S \& T$

community pursues innovation are

a desire to be state-of-the-art, to

use technology better, and to

respond to the customer. However

innovation was not well integrated

into their business and technology

strategies, which may result in ad

hoc innovation efforts that are

incongruent. Therefore, the S\&T

community may be better served

by providing its workforce with

the organizational processes to

better facilitate game-changing

$$
\text { innovation. }
$$

DC serve as a link for transforming

internal and external resources

(specialized know-how, capital,

operational management capability,

Resource integration capability, resource

To analyze how firms

Wu and Wang [41] performance reconfiguration capability, learning capability, ability to

respond to the rapidly changing environment reputation, cooperative alliance

experience) first into firm

competitiveness and then into financial performance.(Dynamic capabilities increase with firm
Technology-based firms in Taiwan
Quantitative
Air Force Research

Laboratory
Qualitative interviews resources and with the willingness

of support firms to cooperate, and,

in turn, they serve to increase firm

competitiveness and then financial performance.) 
Table 1. Cont.

Reference

Purpose

To look at how the existing

literature at the company

level can inform us about

adaptation in new

technology-based companies

Adaptation$$
\text { s (MSI) }
$$
Model that proposes initial as well
as later-acquired human,
technological, financial, and
networking resources as possible
enablers for business model adaptation, which consists of different episodes, characterized by uncertainty or ambiguity.
To investigate the relationship between the marketing

strategy innovativeness and new product performance
Marketing strategy innovativeness (MSI)
Atuahene-Gima et al. [43]

The team's extra industry

relationships and market dynamism enhanced the impact of MSI on new product performance.

In contrast, top management team's intra-industry relationships, financial relationships, and

Technology-based firms in China

Quantitative

technology dynamism hindered

the impact of MSI on new product performance.

A history of increased efforts in

developing and maintaining

marketing capabilities is an

To examine the effects of the dynamics, management, and governance of R\&D and marketing resource

Kor and Mahoney [27] deployments on firm-level economic performance
R\&D and marketing capabilities
Technology-based

entrepreneurial firms in the medical, surgical, and dental instruments industry enduring source of competitive advantage. Moreover, if existing $R \& D$ capabilities are not renewed, in a high-velocity business world, economic rents from prior firm-level capabilities dissipate rapidly. Management experience moderates this effect.
Methodology

Conceptual

New technology-based firms 
Articles in the second group, encompassing contributions that are more recent, start to look at how dynamic capabilities are formed, thus examining antecedents of specific dynamic capabilities, such as ambidexterity [37], exploration and exploitation capabilities [35], or innovative capacity [31]. Overall, antecedents are found at three main levels, namely the individual, organizational, and partner levels. At the individual level, skills [31] are mentioned as important antecedents, with particular reference to the attitude towards adaptability and a strong previous knowledge base [35]. At the organizational level, routines and processes and mechanisms of learning and knowledge governance seem to serve to innovative capacity [31]; in particular, routines in systematizing existing knowledge and experience are given particular emphasis for their potential to transform that knowledge into future capabilities [35]. Finally, partnerships seem to contribute to develop sensing and seizing capabilities [33].

It is clear that the literature on how dynamic capabilities are formed is scant and that there is a lack of an overarching view on antecedents at different levels. In addition, it mainly focuses on new technology-based firms, leaving the other R\&D organizations unexplored. Moreover, there is only one article [41] specifically dealing with the ability to respond to a rapidly changing environment, but only as one of the components through which the impact of dynamic capabilities on firm competitiveness and performance is tested. Therefore, the dimension of speed has not received the attention it deserves.

To bridge this gap, this article aims to understand how an R\&D organization can rapidly take advantage of the opportunities offered by the COVID-19 outbreak and to unveil the factors that enable the organizational speed of an R\&D organization in the face of the COVID-19 outbreak.

\section{Methodology}

We employed a qualitative methodological approach for its ability to capture evolutionary, relational, temporal, and cultural complexities and offer detailed and contextualized descriptions of actions and interactions associated with the innovation domain [44]. We relied on the recent article by Elsahn et al. [45] that aims to provide directions for more rigorous and transparent case studies in the field of technology and innovation management. Our study follows an approach that adopts a variance ontology with a process epistemology [46] in trying to describe innovation processes in terms of stages, phases, or cycles identifying causal relationships. Following the suggestion to select multiple cases or an exemplary single case theoretically proposing a strong justification, we selected the exemplary case of a small R\&D organization, Polo GGB (Pole of Innovation in Genomics, Genetic and Biology), because it represents a "revelatory case" [47] of rapid reaction to the challenges posed by the COVID-19 outbreak. Moreover, it is set in Italy, which was the first country (after China) where the virus spread dramatically.

The rapidity Polo GGB shows in quickly adapting to the challenges posed allowed us to carry out an in-depth analysis of a complex phenomenon, analyzing it from different perspectives and precisely while things were happening. This is particularly important to increase internal validity of results and to avoid the risk that informants do not remember relevant events precisely [48]. Actually, this approach aims to understand the intricacies and complexity of the matter object of study by allowing researchers to unveil meaningful features of real-life events [49]. In addition, this responds to the recent push for research designs that are more focused on specific empirical phenomena based on a rich and contextualized qualitative approach [50]. Providing such a detailed analysis is timeconsuming and implies a significant involvement of respondents, which was not simple at all considered the contingent situation related to the COVID-19 pandemic and pressure on organizations. This contributes to our opting for a single exemplary case where the object of analysis is likely to be detectable, as recommended by Pettigrew [51]. Indeed, when the COVID-19 pandemic exploded, the chosen R\&D organization was strongly motivated and committed to launch new products and services in the market as soon as possible, which let us observe what it did and what allowed it to do so. Therefore, the purpose is to 
develop new understanding and knowledge in a context of novel arrangements (i.e., the COVID-19 pandemic), exploring an under-investigated topic (i.e., organizational speed) from a pragmatic point of view and in line with what the literature suggests is feasible and appropriate for a single case study research (e.g., [52]).

The unit of analysis of this study is the organization, but we enlarged the scope of investigation with the intent to capture diverse elements that enabled organizational speed (i.e., at the individual, organizational, and partner levels). Methodologically, this was done by triangulating the data at distinct levels in the organization, as explicitly suggested by Ritala et al. [50], to cope with level multiplicity in innovation management research.

For this purpose, both authors carried out eight interviews with the CEO and two scientists from Polo GGB following the research protocol (available upon request), which were recorded and transcribed to increase reliability [53]. After a preliminary interview, the CEO was selected as the main key informant due to her deep knowledge and involvement in all ongoing initiatives in the organization regarding both strategic and operational aspects, as frequently happens in small organizations. Furthermore, we interviewed two researchers with a senior position and responsibility for projects who were selected in different areas of research of Polo GGB to get complementary feedback from employees at a different level in the organization, as anticipated. Using multiple sources of evidence and having different researchers involved in data collection are techniques that contribute to constructing validity and reliability, respectively. Data were collected on different occasions, approximately one per week, to have the possibility, on the one hand, to follow the course of events as they happened and, on the other hand, to understand well the relationship between events and connection with the theory. This allowed us to go into deeper details of the different facts interview by interview and sharpen interview protocols according to the theoretical background. During these interviews, we collected information on several aspects: the organization activities and structures, the new projects launched within the COVID-19 domain, the recognition of opportunities, the decision-making process, the execution of projects, and the factors that enabled the organization to be so rapid in taking advantage of opportunities offered after the COVID-19 outbreak. We also checked secondary sources such as reports and YouTube videos to increase the reliability of the data.

Considered the fast-paced nature of the study, immediately after each interview, one of the researchers wrote extensive minutes that carefully documented the questions asked, the responses given, and other relevant observations. Each researcher analyzed data collected independently, inferring some understandings that were then discussed to converge towards a shared interpretation.

To ensure the quality of data, we triangulated information derived from primary data with secondary sources, as archival analysis. To further increase construct validity, we asked the key informants to review the case study draft.

Data analysis involved identifying categories or data themes, as well as sub-categories, naming them, and finding relationships among these categories and data themes, as recommended by the literature (e.g., $[47,49])$. This step reflects the standard coding process, which, in this study, was partially "theory-driven" [54] since most categories were not unknown to the literature. The technique was to code the transcript of interviews, grouping together quotes by means of a thematic criterion, so that they pointed to the same construct and had a connection with organizational speed. Figure 1 exhibits an example of the coding process.

We made extensive use of tables to organize and present data [55,56], thus making evidence emerge from the analysis, which was the result of a reiterated process of examining the data, going over the theory, and going back to the data. The comparison of evidence with the literature during data analysis contributes to increasing external validity [53]. 


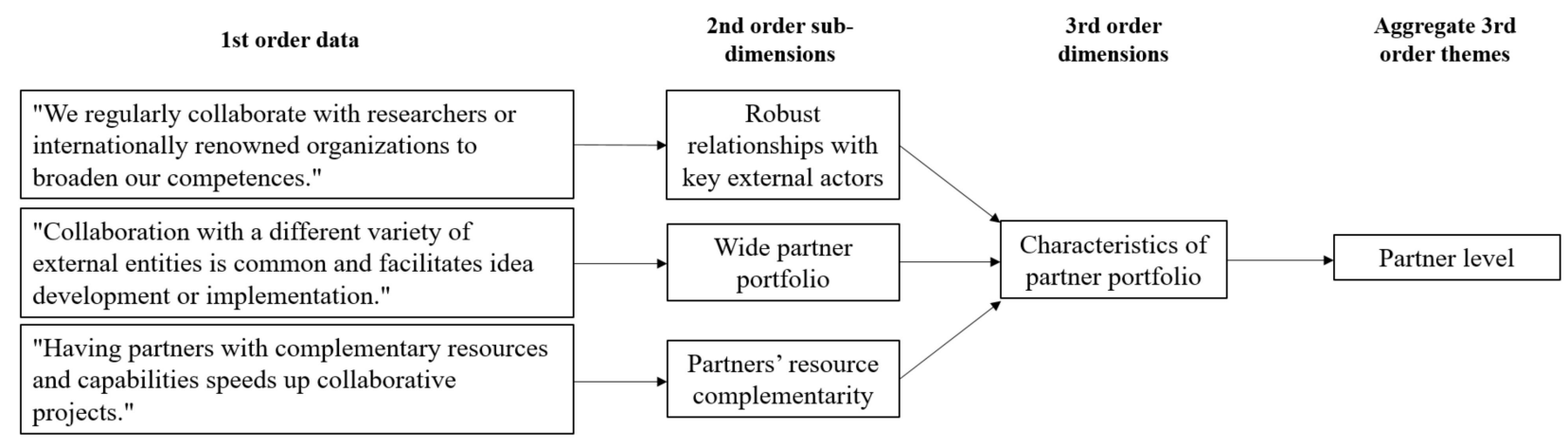

Figure 1. Example of coding-main dimensions and themes that emerged during the interviews.

\section{Results}

\subsection{Case Description}

Polo GGB is a small R\&D organization and a service facility employing 19 people and founded in 2011 mainly by private companies, with the minor participation of one university. This center of excellence provides operational capacity for innovation and research infrastructure for projects involving genetics, genomics, biology, microbiology, human diagnostics, agro-food, and environment. In particular, it provides researchers with leading-edge facilities holding some of the most advanced instruments in three different laboratories: Genomics \& Bioinformatic Laboratory, Ecology and Genetics Research Center, and the Immunology Laboratory. The Genomic and Computational Facility of Polo GGB, located in a bio-incubator inside the Tuscany Life Science and Pharma Valley district in central Italy, has two main objectives: driving innovation in genetics and genomics and promoting technology transfer with industry, with a strong competence in sequencing applications in all fields of biology. The Ecology \& Genetics Research Centre is involved in state-of-the-art research projects aimed at developing genetic measures for the control of vector-borne diseases (malaria). The Immunology Laboratory is specialized in the production of monoclonal antibodies. These two laboratories are located in Terni within the Medicine Campus of the University of Perugia, still in the center of Italy but in an adjoining region.

The pool of competences this R\&D organization possesses makes this case particularly relevant; indeed, the CEO explains: "Genomics, molecular biology, and immunodiagnostics serve the purpose of COVID-19-related projects; they are a sort of tools to develop projects, and we have all of them inside our organization". This feature is not common in such small organizations, which, combined with the strength of speed, repeatedly stressed by interviewees ("Our strength is speed of action and reaction to changes"), makes this case exemplary to inform academics and practitioners regarding best practices to be prepared to face disruptive changes in the environment, such as the COVID-19 pandemic. Finally, yet importantly, Polo GGB, being involved in a number of projects that have a high scientific value, has been able to combine speed with quality of projects, overcoming the common tension between speed or efficiency and quality or accuracy (e.g., [57]), which further contributes to making it a case of excellence.

\subsection{How to Take Advantage of Opportunities Deriving from the COVID-19 Outbreak Rapidly}

In this paragraph, we describe how Polo GGB was able to react quickly to the COVID19 outbreak, showing a high level of organizational speed, in all of its three components, namely recognition, decision, and execution.

\subsubsection{Recognition Speed}

The COVID-19 pandemic has posed many challenges in different fields, such as economics, improvement of healthcare systems, safety, and security. In the healthcare domain, the widely recognized opportunities have revolved around the development of a 
drug against COVID-19 and of swabs and serologic tests to detect the presence of the virus and antibodies, respectively.

In this scenario, the CEO of Polo GGB, who holds the responsibility for launching and managing projects for the organization, immediately senses the opportunity to use the competences of the Polo along two main lines: "We are able to help and we are able to do business in this situation", she asserts.

Different idea generation sessions, organized very rapidly with the purpose of understanding what they can do practically, are organized. The first outcome is the recognition of the type of competences they have and how they could be used fruitfully, as the CEO outlines: "We have the competences in molecular biology, and we have an authorization to do diagnostics; let's exploit them and work immediately to validate the test to search for COVID-19 antibodies in real time". In other words, the small R\&D laboratory does not put routinized procedures in place for scanning the external environment, but mainly decides to analyze the scientific and multidisciplinary internal competences they possess to promptly recognize the opportunities they could pursue. This allows them to identify potentially interesting ideas even though they are not in their core business, as the CEO highlighted: "We have never realized a real-time test with a diagnostic purpose, but we can do it". This means they are able to re-think their way of doing business by combining the emergent opportunities with alternative use of their competence with respect to their standard way of doing business.

Furthermore, the role of an outstanding Scientific Director of the Polo, based at the University of Padova, must also be stressed: as the CEO outlines "This new idea is an epiphany of our Scientific Director", which means that the intuition of scientists can make the difference in recognizing an opportunity in a timely manner.

In parallel with internal actions to identify opportunities, external ideas are also evaluated: "We always welcome ideas coming from outside our company and never discard them a priori". On such a basis, despite the intense activity within the company, the CEO and staff accept discussion of proposals from other firms or institutions without delaying them as explicitly declared: "A firm contacted us thanks to a collaboration I had years ago with a business angel that is now part of the advisory board of that firm, and I started listening and discussing with them straightaway".

To summarize, the recognition phase has proceeded internally and externally without excluding any idea and trying to catch the necessary information as soon as possible to check the feasibility and interest for Polo GGB.

\subsubsection{Decision Speed}

Thanks to the degrees of freedom the CEO has in terms of decisions on which projects to launch, she quickly shares the ideas and opportunities with the Scientific Director of Polo GGB to verify their scientific value and feasibility: "Polo GGB has a very quick decision process and the possibility to set aside funds for research: it can use them without the intervention of the Board if the investments are below 40,000 euros, as in the case of COVID-19-related projects", the CEO explains. "Moreover", she adds, "I have daily contact with the Scientific Director to check the feasibility and quality of the projects". Overall, among the different opportunities that emerged, four new projects are launched in a very short time lapse, as the CEO confirms: "We, the Scientific Director and I, took the decision to proceed with these projects in a few hours". She also explains that this is not the standard way of progressing: "Normally, we make a business plan [ ... ], but in this case we had to be fast in deciding to start with the project, so we gave priority to reaching the aim instead of doing the best financial choices; for example, we considered technological feasibility and quality of the output first instead of preparing a detailed budget". This means that preliminary activities involving planning and budgeting, which normally take place before deciding whether to launch a project or not, are given less importance in favor of more operative tasks associated with whether the project could be carried out in practice. 
The decision falls on four main projects, among which two are carried out within the laboratories of Polo GGB, and the other two in collaboration with a set of external partners.

The first internal project has an explorative nature, ambitiously aiming to produce a monoclonal antibody (i.e., a potential drug) against SARS-CoV-2; furthermore, they realize they could use these immunology-related competences to identify SARS-CoV-2 to also develop a serologic test (i.e., direct test to detect whether a person has developed antibodies against SARS-CoV-2). For the second internal project, which is more exploitative, they could use internal competences to execute the real-time analysis of a swab to detect infection by SARS-CoV-2, to be offered as a new service to clients.

As far as project ideas coming from external partners, the first project concerns explorative research to develop a platform for contagion risk management based on an idea developed by the research center MATEMA and the University of Padova. Indeed, the core idea is to identify clusters of employees that are more or less susceptible to SARSCoV-2 based on social, work, and environmental conditions, determining a risk score that can improve decision-making on COVID-19 test execution. This project can contribute to active surveillance of COVID-19 spread and, thus, safety in workplaces. Polo GGB is contacted for its strong ability to analyze swabs and manage the logistics of swabs, considering the relevance of a timely diagnosis of the presence of SARS-CoV-2. For this purpose, on-site campers in remote zones are also set up thanks to the collaboration of a large Italian company.

The second proposal, whose idea comes from the National Centre of Research (CNR) of Italy, has the purpose of validating a method to test for the presence of SARS-CoV-2 in PM10 particles from filters made available by regional agencies for environmental safeguarding. The CEO understands that Polo GGB is called to bridge the lack of instruments required to analyze filters safely, as well as of the possibility to move them safely. The last explorative project departs from an idea of the CEO, who contacted another laboratory in the north of Italy with the aim of defining an algorithm meant to identify conditions increasing the probability of getting infected by COVID-19, which could reveal useful insights for the other ongoing projects.

\subsubsection{Execution Speed}

A few days after the decision to proceed, Polo GGB starts being operative on the four new projects, which are set as priorities. Concretizing these ideas into ongoing projects passes through the rapid re-allocation of different resources to the different new and existing projects, which makes the need for new resource acquisition emerge. As the CEO outlines, "We immediately realized we needed more technicians due to the increase in workload in the laboratories after the COVID-19-related projects, so we hired four new employees straightaway, which, for an organization such as Polo GBB, is a lot". Normally, new employees go through a training period when they are involved in some of the activities of ongoing projects; instead, in this case, "We needed new technicians to be operative immediately; therefore, we integrated them into all project activities, making senior technicians and scientists take responsibility for them" $^{\prime \prime}$, as the CEO and scientists explained. Indeed, in this case and contrarily from what normally happens at Polo GGB, mid-level project leaders are defined and, in general, senior technicians and scientists are given more autonomy and responsibility regarding the new projects. Obviously, this does not exclude the supervision of the CEO: "I have multiple daily meetings, even extemporaneous, with staff to check work in progress, identify problems, and decide how to solve them, and frequent interactions with external partners".

Interviewees admitted they have to face some difficulties in organizing the work and some resistance against some activities, especially at the beginning, but then results are surprising. As the CEO recognizes, "Our team was able to quickly switch from the routinized activities that were mainly related to the genomic domain to molecular biology and diagnostics with a willingness to perform these activities even unexpectedly [ . . ]; they want to be active and help in this emergency situation, and the result is that they react in a proactive manner". 
One last relevant point raised during the interviews is the IT infrastructure: "We put resources and efforts into creating an appropriate IT infrastructure to support the new activities that need to be done rapidly. Normally, we didn't need it, or at least we were used to a less developed infrastructure, but now that we have it, it is another opportunity". The high quantity of tests to be processed requires strengthening the IT infrastructure to proceed more rapidly.

What is interesting for this study, beyond the scientific value of the projects that may have a significant impact on society, is the richness and variety of initiatives that a small R\&D organization has been able to launch in such a short time span since the COVID-19 pandemic. Indeed, Polo GGB has gone through the recognition-decision-execution process in less than three months. Using the words of the CEO: "Catching and developing new ideas and implementing them quickly is key for our organization; I am active in doing it".

\subsection{Antecedents of Organizational Speed}

The data analysis shows that antecedents of organizational speed can be found at three levels, namely the individual, organizational, and partner levels, as described in the following paragraphs.

\subsubsection{Antecedents at the Individual Level}

As far as antecedents at the individual level are concerned, they refer to characteristics of the CEO and of the employees. The CEO clearly explains that human capital in an R\&D organization is at the basis of the ability to react quickly, because if scientists are highly educated, they have a more flexible mindset, which is required to face challenges and solve problems. As the CEO outlines, a company like Polo GGB "needs scientists and technicians with high skills to take advantage of challenging opportunities from the market", and she further stresses, "this profile (where $80 \%$ of the staff have a PhD) is necessary to have flexible resources". People are encouraged "to learn from others in several ways to enlarge their competences and be more flexible".

On the other hand, scientists emphasize the fundamental role of the CEO in terms of proactivity and ability to be a leader while also being part of the team: "(She) is involved in all issues and involves us researchers in the different projects", explains one of the researchers. Moreover, the CEO describes herself as a person who "welcomes challenges; it is in my nature": her strong attitude towards taking risks emerges clearly from the passion in describing the potential relevance, although uncertain, of the new projects. In addition, she explained that she was rapidly able to recognize and evaluate new challenges both at the technical and managerial levels, which reflects her dual competence.

\subsubsection{Antecedents at the Organizational Level}

At the organizational level, the flat organizational structure with a low degree of hierarchy further allows the CEO to make decisions autonomously: "There are no other middle managers between top management and other employees, which speeds up all processes". The organizational context, described by the interviewees as characterized by employees "who normally carry out explorative and exploitative projects" and where "people are used to it and it helps switching from one to another easily", seems to be a fruitful environment to catch the challenges posed by the COVID-19 emergency. Put in other words, the ability to start both explorative and exploitative projects rapidly is obtained through a contextual form of ambidexterity where scientists are used to easily moving between different tasks with a different nature within the same laboratory.

A bundle of broad financial, technological, and knowledge resources complements the flexibility allowed by the scientists and the structure, because it facilitates the number and variety of new projects Polo GGB is able to implement. As the employees declare, "We have a wide variety of technologies available in house, which, together with a wide spectrum of competences, allows us to start new projects easily and rapidly". Moreover, the CEO adds, "financial resources are not a problem for us, and we have visibility on resource availability in the medium term, which poses no problems in carrying out new projects". 
The culture plays a fundamental role in this R\&D organization, and the CEO emphasizes this aspect a lot during the interviews: "We have put a lot of effort into creating a culture of continuous change to be ready to learn new things and adapt to the changing environment rapidly". Indeed, shared values seem to be at the core of their mission and permeate all levels of the organization. The CEO has worked on fostering and stimulating a culture of mutual learning and inclination towards change that looks at the success of the organization instead of at the success of individuals. This culture is reflected by the rewards system, since the company "does not reward individuals, but the team, which is pushed towards accomplishing the team goal". Furthermore, scientists and employees have always been used to working with external partners, because "for a small RED organization such as Polo GGB, being open to collaboration is essential to being more ready and reactive; of course you are able to collaborate if you are an excellence in your field, so our employees are always pushed to maintain a high reputation", the CEO underlines.

Finally, internal operative systems and processes reflect the climate where everybody is motivated to work and interact frequently with colleagues sharing different backgrounds, and communication is facilitated not only horizontally but also vertically. The speediness is also guaranteed by the fact that employees "frequently check the work in progress through meetings, so that if there is a problem, it emerges immediately"; in addition, "communication is frequent and open; we use different channels to be always updated, almost in real time", highlights the CEO. This open line of communication facilitates the monitoring of projects, problem solving, and control of the scientists' work, while maintaining a climate of collaboration. Generally, the employees "are always open to accepting, evaluating, and discussing solutions proposed by third parties to find the most effective ones". This is backed by the fact that scientists and technicians working in teams have different competences, as the CEO explains: "People work in teams, and in each team there are different competences; problem solving is more rapid in this way".

\subsubsection{Antecedents at the Partner Level}

The same open culture has made Polo GGB establish a wide portfolio of relationships with external partners, most of which are based on a complementarity principle. This factor further increases the potential of the organization to recognize new opportunities and implement projects more rapidly due to their previous experience of collaboration and lack of competition. In the words of the CEO, "collaborations with a wide variety of external entities are common and facilitate idea development or implementation"; complementarity among partners seems to play a positive role, as the CEO confirms: "Having partners with complementary resources and capabilities speeds up collaborative projects".

Figure 2 presents an overarching picture of how organizational speed is obtained and the antecedents of organizational speed, which is the main result of this study. 

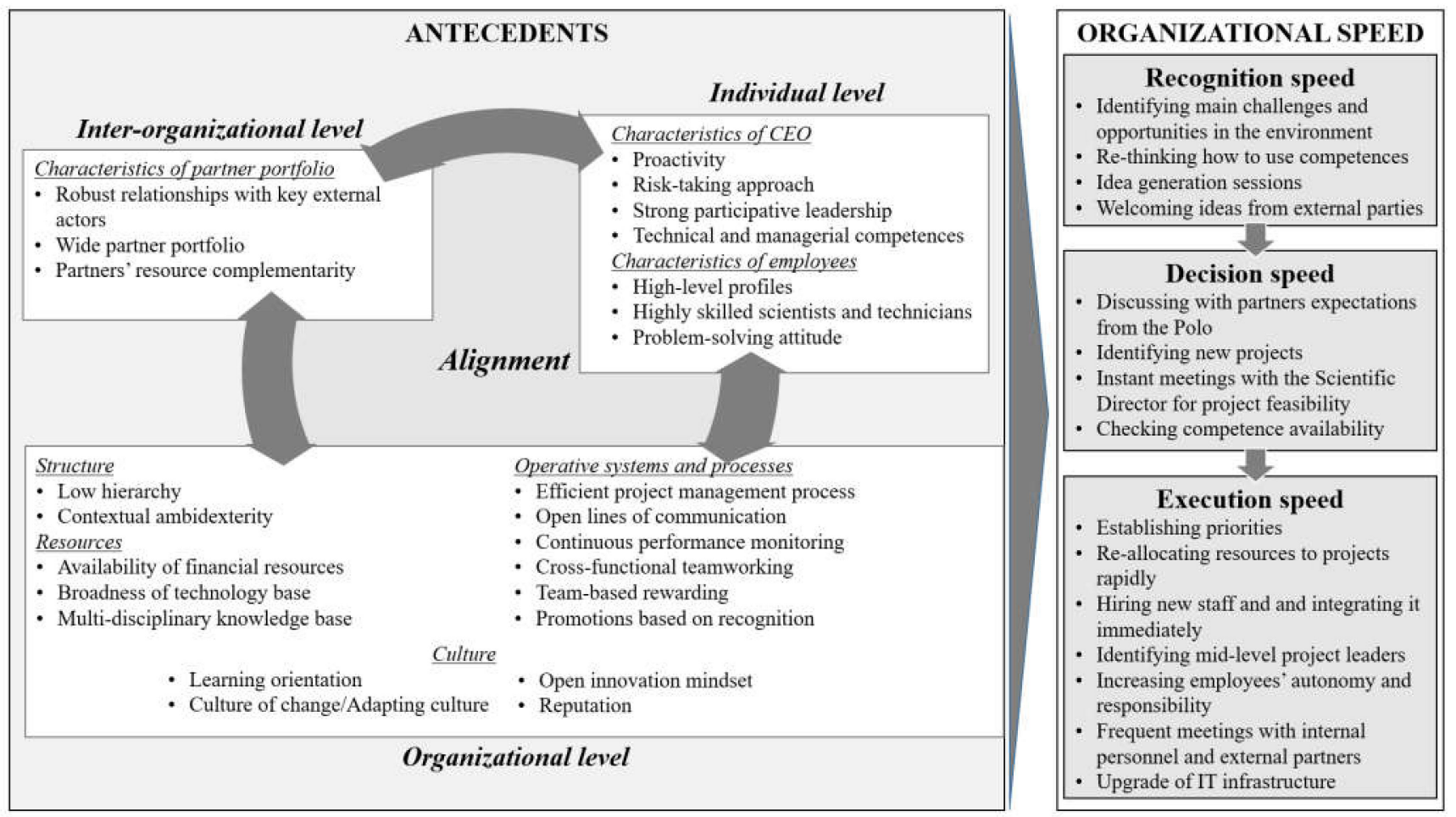

Figure 2. Overview of the antecedents of organizational speed.

\section{Discussion and Conclusions \\ 6.1. Discussion of Findings}

The purpose of this study was to understand how an R\&D organization can rapidly take advantage of the opportunities offered by the COVID-19 outbreak and to unveil the factors that enable the organizational speed of an R\&D organization in the face of the COVID-19 outbreak.

Our case shows that Polo GGB is able to revise its strategy, integrating both explorative and exploitative projects, balancing the exploitation of the current capabilities with developing new ones.

In the face of the dramatic external circumstances, the R\&D organization displays a great ability to adapt its strategic direction to seize the newly emerged opportunities fully; the whole organization is able to respond by adding a new set of projects to the current portfolio, thus keeping pace with the challenges posed by the external environment. Organizational speed is achieved through a quick process that involves fast awareness and recognition, decision, and action. Overall, it seems that the internal scientific competences, jointly with the outstanding profile of the Scientific Director of the Polo, are at the basis of the first two steps. Firstly, Polo GGB recognizes they have a strong and differentiated pool of competences they can use for emerging opportunities, identified through idea generation sessions, despite not being in line with their core business. Secondly, in the decision phase, the attention is focused more on whether the Polo has all the competences required for the project and whether the project is feasible from a technological point of view, rather than on detailed planning and budgeting. During the execution phase, these new projects become operative very rapidly, revealing the strong potential of the small $R \& D$ organization that is the object of study. Indeed, through a rapid reallocation of resources and the hiring of new employees who become operative straightaway thanks to the supervision of senior technicians and researchers who are granted enhanced autonomy and responsibility, Polo GGB has reached the first results in a record time.

Results show there is a set of factors that enable the CEO to successfully recognize and act promptly when it is time to boost changes and to quickly commit the resources to new courses of actions in response to such changes. According to the few previous 
contributions on dynamic capabilities in R\&D organizations, these factors are spread out over three different levels, namely the partner, organizational, and individual levels. For organizational speed to be increased, the combination of the specific identified elements at the three levels enables a quick recognition, decision, and execution process: what we add to the previous debate is an overarching and integrated picture of these antecedents that jointly allow these small R\&D organizations to react promptly.

At the partner level, the open innovation attitude combined with the company's reputation, also boosted by the fact of having two laboratories located in an incubator and another one in a university, enables the proliferation of interesting external opportunities and partnerships and facilitates the identification and subsequent execution of some of the new projects. Furthermore, the partnerships already in place facilitate the scanning and sensing of new opportunities and projects as well as their subsequent execution. At the organizational level, the flat organization with a low hierarchy favors a climate of effective open communication and collaboration throughout the organization, where silos are broken up; as a result, employees are used to working in a team, where their multidisciplinary competences are enhanced and a process of mutual learning and cooperation is encouraged. The incentive system and the values of the organization promote cooperation instead of competition, nurtured by the fact that the evaluation is made on the team instead of on the individuals. At the individual level, employees are fully embodied in the culture and systems of the organization, handling exploitative and exploratory activities simultaneously. Furthermore, the strong knowledge in several different scientific fields and the commitment devoted to its development allow the company to be flexible in accepting new projects. In other words, commitment and flexibility coexist and contribute to organizational speed; this flexibility is rooted in the deep knowledge and experience of the organization in the three main scientific fields, representing the core competences, developed over time, which permits the generation of options for future explorative and exploitative projects.

Overall, the organization's attitude towards teamwork, the multidisciplinary collaboration among departments, the availability of financial resources, the partnership ecosystem, and the creativity and skills of the employees combined with their strong attitude in problem solving are all fundamental ingredients of the formula that leads the company to show this high level of organizational speed. These factors, embracing the partner, organizational, and individual levels, are inter-related, aligned, and mutually reinforcing. The principles and values of the organization permeate the systems, the practices, and the behavior of employees, fully nurtured by the strong participative leadership style of the $\mathrm{CEO}$ who is able to mentor and at the same time coach, orchestrate, and bring together diverse employees to create an effective team [57-59]. Furthermore, the existing contextual ambidextrous structure makes it possible to realize the strategic goals of the company on several fronts, also thanks to the highly skilled personnel of the laboratories. It seems that the organization, at a time just as the new projects are introduced, is well-aligned along its central building blocks (structure, strategy, system, share value, style, skills, staff), often mentioned by the literature [60] as fundamental for firm competitive advantage. Indeed, maintaining the alignment along these elements keeps on being a key priority for the CEO: the implementation of new projects is consistent with the organizational structure of the laboratories and the systems in place; the new staff share the systems and values of the organization; cross-functional teams are maintained as much as possible, thanks to the support of virtual technologies. This allows the organization and the employees to reconfigure their activities to embrace these new opportunities in their daily work and strive to work together to achieve clear and consistent goals, while avoiding tensions and conflicts that could have emerged. While previous contributions on DC in R\&D organizations have mainly investigated some specific factors, this study emphasizes the importance of having a set of different factors at different levels aligned and working in a synergic way to reach high levels of organizational speed. 


\subsection{Theoretical and Practical Implications and Limitations}

This study offers some interesting theoretical and practical implications.

From an academic standpoint, the present article extends the literature on organizational speed and dynamic capabilities from the context of manufacturing firms to the much less investigated context of R\&D organizations. Furthermore, it offers an overarching picture of how a combination of different and aligned elements allows an R\&D organization to face the challenges posed by the COVID-19 outbreak promptly. Other studies can further enrich this literature by deeply investigating the interplay among the different enablers and the role of the CEO, as well as by shedding light on the process that leads to organizational speed, maybe enlarging the studies to other R\&D organizations of different sizes and industries. Considering the increasingly mutable social, economic, and environmental scenario, R\&D theorists are likely to be particularly interested in a better understanding of how R\&D organizations or departments can face disruptive changes efficiently, as well as how they can prepare to be ready to do so. This study, aiming to elaborate on organizational speed, goes in that direction by providing an overarching picture on how to unfold the recognition-decision-execution process rapidly and identifying antecedents at the individual, organizational, and partner levels, which represented a gap in the literature. In addition, it contributes to the recent stream connecting the triple bottom-line dimensions of environmental, social, and economic sustainability with the COVID-19 pandemic (e.g., [3,61]), with particular attention on economic sustainability.

From a managerial viewpoint, the case shows that the antecedents of organizational speed are located at different levels of the organization, in the mind and knowledge of employees, in the values, systems, and processes in which they are embodied, and in the ecosystem of external relationships. In this context, CEOs must play the role of orchestrators who keep the communication channels open, interacting consistently, frequently, and effectively with employees and other stakeholders about strategic goals, priorities, and values. Due to the small size of the organization, the CEO becomes the point of reference for all employees and can easily expand the decision portfolio, adding variations to the initiatives already in place [62]. Managers of small R\&D organizations should interestingly notice that an upgrade of the IT infrastructure is required to speed up processes, as widely recommended by the literature (e.g., [63]), which suggests investments in this area are useful even in those contexts where a deep use of IT is not widespread. At the same time, investments in improving the infrastructure, or in more general processes, may offer further opportunities to change the standard way of doing things, leading to processes that are more efficient. This example suggests that the first move towards change may be the most difficult one, but then it can open new scenarios for development in small contexts.

With particular reference to the global practicalities of curtailing the COVID-19 pandemic, this study can have an impact by showing how small R\&D organizations can react to the disruption this outbreak has brought about and proving the fundamental role they can play in this situation thanks to their ability to react promptly. Small R\&D organizations that have the right intuition and a structure able to support innovative ideas are making the difference in such a challenging situation.

Of course, we recognize the limitations related to the analysis of a single case, which prevents us from making our analysis generalizable to different contexts. For this purpose, future qualitative research could contribute to replicating or enriching our proposed framework across multiple settings, and subsequent quantitative studies could statistically test relationships among variables.

Author Contributions: Conceptualization, L.A. and A.N.; methodology, L.A. and A.N.; formal analysis, L.A. and A.N.; writing-original draft preparation, L.A. and A.N.; writing-review and editing, L.A. and A.N.; project administration, L.A. and A.N. All authors have read and agreed to the published version of the manuscript.

Funding: This research received no external funding.

Institutional Review Board Statement: Not applicable. 
Informed Consent Statement: Informed consent was obtained from all subjects involved in the study.

Conflicts of Interest: The authors declare no conflict of interest.

\section{References}

1. Surico, P.; Galeotti, A. The Economics of a Pandemic: The Case of COVID-19, London Business School. 2020. Available online: https:/ / www.dropbox.com/s/wm521646rszp190/slides_COVID19_final.pdf?dl=0 (accessed on 1 December 2020).

2. Rai, S.S.; Rai, S.; Singh, N.K. Organizational resilience and social-economic sustainability: COVID-19 perspective. Environ. Dev. Sustain. 2021, 23, 1-18. [CrossRef] [PubMed]

3. Jiang, J.; Park, E.-M.; Park, S.-T. The Impact of the COVID-19 on Economic Sustainability-A Case Study of Fluctuation in Stock Prices for China and South Korea. Sustainability 2021, 13, 6642. [CrossRef]

4. Sarkis, J. Supply chain sustainability: Learning from the COVID-19 pandemic. Int. J. Oper. Prod. Manag. 2020, 41, 63-73. [CrossRef]

5. Birkinshaw, J.; Zimmermann, A.; Raisch, S. How do firms adapt to discontinuous change? Bridging the dynamic capabilities and ambidexterity perspectives. Calif. Manag. Rev. 2016, 58, 36-58. [CrossRef]

6. Sanchez, R. Strategic flexibility in product competition. Strat. Manag. J. 1995, 16, 135-159. [CrossRef]

7. Li, Y.; Su, Z.; Liu, Y.; Li, M. Fast adaptation, strategic flexibility and entrepreneurial roles. Chin. Manag. Stud. 2011, 5, $256-271$. [CrossRef]

8. Dykes, B.J.; Hughes-Morgan, M.; Kolev, K.D.; Ferrier, W.J. Organizational speed as a dynamic capability: Toward a holistic perspective. Strat. Organ. 2018, 17, 266-278. [CrossRef]

9. Horst, S.O.; Järventie-Thesleff, R.; Baumann, S. The practice of shared inquiry: How actors manage for strategy emergence. J. Media Bus. Stud. 2019, 16, 202-229. [CrossRef]

10. Schwarz, G.M.; Stensaker, I. Researching a Pandemic: Letting COVID-19 Drive Our Research. J. Appl. Behav. Sci. 2020, 56, 261-265. [CrossRef]

11. Amis, J.M.; Janz, B.D. Leading Change in Response to COVID-19. J. Appl. Behav. Sci. 2020, 56, 272-278. [CrossRef]

12. Arora, P.; Suri, D. Redefining, relooking, redesigning, and reincorporating HRD in the post Covid 19 context and thereafter. Hum. Resour. Dev. Int. 2020, 23, 438-451. [CrossRef]

13. Gerald, E.; Obianuju, A.; Chukwunonso, N. Strategic agility and performance of small and medium enterprises in the phase of Covid-19 pandemic. Int. J. Financ. Account. Manag. 2020, 2, 41-50. [CrossRef]

14. Akhigbe, E.A.; Onuoha, B.C. Strategic Agility and Organizational Resilience of Food and Beverage Firms in Rivers State, Nigeria. Int. J. Bus. Syst. Econ. 2019, 12, 80-93.

15. Chesbrough, H. To recover faster from Covid-19, open up: Managerial implications from an open innovation perspective. Ind. Mark. Manag. 2020, 88, 410-413. [CrossRef]

16. Hirt, M.; Laczkowski, K.; Mysore, M. Bubbles Pop, Downturns Stop. McKinsey Quarterly. 2019. Available online: https://www. mckinsey.com/business-functions/strategy-and-corporate-finance/our-insights/bubbles-pop-downturns-stop (accessed on 1 February 2021).

17. Verma, S.; Gustafsson, A. Investigating the emerging COVID-19 research trends in the field of business and management: A bibliometric analysis approach. J. Bus. Res. 2020, 118, 253-261. [CrossRef] [PubMed]

18. Liu, Y.; Lee, J.M.; Lee, C. The challenges and opportunities of a global health crisis: The management and business implications of COVID-19 from an Asian perspective. Asian Bus. Manag. 2020, 19, 277-297. [CrossRef]

19. Shani, A.B.; Coghlan, D.; Alexander, B.N. Rediscovering abductive reasoning in organization development and change research. J. Appl. Behav. Sci. 2020, 56, 60-72. [CrossRef]

20. Yi, Y.; He, X.; Ndofor, H.; Wei, Z. Dynamic Capabilities and the Speed of Strategic Change: Evidence from China. IEEE Trans. Eng. Manag. 2014, 62, 18-28. [CrossRef]

21. Kraatz, M.S.; Zajac, E.J. How organizational resources affect strategic change and performance in turbulent environments: Theory and evidence. Organ. Sci. 2001, 12, 632-657. [CrossRef]

22. Abdelilah, B.; El Korchi, A.; Balambo, M.A. Flexibility and agility: Evolution and relationship. J. Manuf. Technol. Manag. 2018, 29, 1138-1162. [CrossRef]

23. Nafei, W.A. Organizational agility: The key to organizational success. Int. J. Bus. Manag. 2016, 11, $296-309$.

24. Singh, J.; Sharma, G.; Hill, J.; Schnackenberg, A. Organizational agility: What it is, what it is not, and why it matters. In Academy of Management Proceedings; Academy of Management: Briarcliff Manor, NY, USA, 2013; Volume 1, pp. 1-40.

25. Baškarada, S.; Koronios, A. The 5 S organizational agility framework: A dynamic capa-bilities perspective. Int. J. Organ. Anal. 2018, 26, 331-342. [CrossRef]

26. Walter, A.T. Organizational agility: Ill-defined and somewhat confusing? A systematic literature review and conceptualization. Manag. Rev. Q. 2020, 1-49. [CrossRef]

27. Kor, Y.Y.; Mahoney, J.T. How dynamics, management, and governance of resource deployments influence firm-level performance. Strat. Manag. J. 2005, 26, 489-496. [CrossRef]

28. Biedenbach, T.; Müller, R. Absorptive, innovative and adaptive capabilities and their impact on project and project portfolio performance. Int. J. Proj. Manag. 2012, 30, 621-635. [CrossRef] 
29. Thal, A.E., Jr.; Shahady, D.E. Innovation in a military research laboratory: An initial exploratory study. Technol. Anal. Strateg. Manag. 2010, 22, 171-187. [CrossRef]

30. Löfsten, H. Organisational capabilities and the long-term survival of new technology-based firms. Eur. Bus. Rev. 2016, 28, 312-332 [CrossRef]

31. Do Nascimento Welter, C.V.; Sausen, J.O.; Rossetto, C.R. The development of innovative capacity as a strategic resource in technology-based incubation activities. Rev. Gestão 2020, 27, 169-188. [CrossRef]

32. Deligianni, I.; Voudouris, I.; Spanos, Y.; Lioukas, S. Non-linear effects of technological competence on product innovation in new technology-based firms: Resource orchestration and the role of the entrepreneur's political competence and prior start-up experience. Technovation 2019, 88, 102076. [CrossRef]

33. Salehi, F.; Zolkiewski, J.; Perks, H.; Bahreini, M.A. Exploration of capability and role development in an emerging technology network. J. Bus. Ind. Mark. 2018, 33, 931-944. [CrossRef]

34. Deakins, D.; Bensemann, J. Entrepreneurial learning and innovation: Qualitative evidence from agri-business technology-based small firms in New Zealand. Int. J. Innov. Learn. 2018, 23, 318-338. [CrossRef]

35. Jensen, A.; Clausen, T.H. Origins and emergence of exploration and exploitation capabilities in new technology-based firms. Technol. Forecast. Soc. Change. 2017, 120, 163-175. [CrossRef]

36. Cho, C.; Son, J.K.; Lee, S.; Park, S. Comparative Analysis of R\&D-Based Innovation Capabilities in SMEs to Design Innovation Policy. Sci. Public Policy 2016, 44, 403-416.

37. Hutterer, P.; Gattringer, R.; Irschik, H.; Strehl, F. Managing Contradictory Stakeholder Demands of a Publicly Funded Research Center. Int. J. Innov. Technol. Manag. 2015, 12, 1550002. [CrossRef]

38. Ortín-Ángel, P.; Vendrell-Herrero, F. University spin-offs vs. other NTBFs: Total factor productivity differences at outset and evolution. Technovation 2014, 34, 101-112. [CrossRef]

39. Brinckmann, J.; Hoegl, M. Effects of initial teamwork capability and initial relational capability on the development of new technology-based firms. Strat. Entrep. J. 2011, 5, 37-57. [CrossRef]

40. Strehle, F.; Katzy, B.R.; Davila, T. Learning capabilities and the growth of technology-based new ventures. Int. J. Technol. Manag. 2010, 52, 26-45. [CrossRef]

41. Wu, L.-Y.; Wang, C.-J. Transforming resources to improve performance of technology-based firms: A Taiwanese Empirical Study. J. Eng. Technol. Manag. 2007, 24, 251-261. [CrossRef]

42. Andries, P.; De Backere, K. Adaptation in new technology-based ventures: Insights at the company level. Int. J. Manag. Rev. 2006, 8, 91-112. [CrossRef]

43. Atuahene-Gima, K.; Li, H.; De Luca, L.M. The contingent value of marketing strategy innovativeness for product development performance in Chinese new technology ventures. Ind. Mark. Manag. 2006, 35, 359-372. [CrossRef]

44. Garud, R.; Tuertscher, P.; Van de Ven, A.H. Perspectives on innovation processes. Acad. Manag. Ann. 2013, 7, 775-819. [CrossRef]

45. Elsahn, Z.; Callagher, L.; Husted, K.; Korber, S.; Siedlok, F. Are rigor and transparency enough? Review and future directions for case studies in technology and innovation Management. RED Manag. 2020, 50, 309-328.

46. Van de Ven, A.H.; Poole, M.S. Alternative approaches for studying organizational change. Organ. Stud. 2005, $26,1377-1404$. [CrossRef]

47. Yin, R.K. Case Study Research: Design and Methods, 4th ed.; Sage: Thousand Oaks, CA, USA, 2009.

48. Voss, C.; Tsikriktsis, N.; Frohlich, M. Case research in operations management. Int. J. Oper. Prod. Manag. 2002, 22, 195-219. [CrossRef]

49. Gaya, H.J.; Smith, E.E. Developing a qualitative single case study in the strategic management realm: An appropriate research design. Int. J. Bus. Manag. Econ. Res. 2016, 7, 529-538.

50. Ritala, P.; Schneider, S.; Michailova, S. Innovation management research methods: Embracing rigor and diversity. RED Manag. 2020, 50, 297-308.

51. Pettigrew, A.M. Longitudinal Field Research on Change: Theory and Practice. Organ. Sci. 1990, 1, 267-292. [CrossRef]

52. Mukhija, V. N of One plus Some: An Alternative Strategy for Conducting Single Case Research. J. Plan. Educ. Res. 2010, 29, 416-426. [CrossRef]

53. Riege, A.M. Validity and reliability tests in case study research: A literature review with "hands-on" applications for each research phase. Qual. Mark. Res. Int. J. 2003, 6, 75-86. [CrossRef]

54. Ryan, G.W.; Bernard, H.R. Data management and analysis methods. In Handbook of Qualitative Research, 2nd ed.; Denzin, N., Lincoln, Y., Eds.; Sage: Thousand Oaks, CA, USA, 2000; pp. 769-802.

55. Miles, M.B.; Huberman, A.M. Qualitative Data Analysis: An Expanded Sourcebook; Sage: Thousand Oaks, CA, USA, 1994.

56. Eisenhardt, K.M.; Graebner, M.E. Theory building from cases: Opportunities and challenges. Acad. Manag. J. 2007, 50, 25-32. [CrossRef]

57. Johnson, L.A.; Hayashi, H. Synthesis Efforts in Disaster Recovery Research. Int. J. Mass Emergencies Disasters 2012, $30,212-238$.

58. Keller, R.T. A longitudinal study of the individual characteristics of effective R\&D project team leaders. RED Manag. 2017, 47, 741-754.

59. Kim, C.C.; Hays, J.M. The Australian National University Renaissance Leaders Global Trends and Emerging Forms of Leadership. J. Manag. 2010, 4, 1-27.

60. Feurer, R.; Chaharbaghi, K. Strategy development: Past, present and future. Manag. Decis. 1995, 33, 11-21. [CrossRef] 
61. Bartle, J.; Lutte, R.; Leuenberger, D. Sustainability and Air Freight Transportation: Lessons from the Global Pandemic. Sustainability 2021, 13, 3738. [CrossRef]

62. Jacobs, P. Five steps to thriving in times of uncertainty. Harv. Manag. Update 2005, 10, 1.

63. Cai, Z.; Liu, H.; Huang, Q.; Liang, L. Developing organizational agility in product innovation: The roles of IT capability, KM capability, and innovative climate. RED Manag. 2019, 49, 421-438. 